Post-Medieval Archaeology 50/1 (2016), 92-107

\title{
The post-medieval rural landscape: towards a landscape \\ archaeology?
}

\section{By JEMMA BEZANT and KEVIN GRANT}

SUMMARY: This article examines the evidence for engagement with the rural post-medieval landscape using two national case studies: Wales and Scotland. The issues reflected in these case studies are indicative of the wider challenges for archaeologists and professional practitioners alike. The article recognizes that landscape is not just about geographical place, but an archaeological theoretical framework. It proposes that Post-Medieval Archaeology monographs and conference sessions specific to landscape could help to tease out themes that address the big questions of the post-medieval world - capitalism, modernity and improvement — but also take account of agency, identity and meaning. 
The Post-Medieval Rural Landscape - toward a landscape archaeology?

Authors: Dr Jemma Bezant (University of Wales Trinity St. David) and Kevin Grant (University of Glasgow)

Abbreviated Title: The Post-Medieval Rural Landscape

Word Count: 7916

Date Submitted: 1.9.15, Accepted March 2016

Jemma Bezant

School of Archaeology, History \& Anthropology

University of Wales Trinity Saint David

College Street, Lampeter

Ceredigion

SA48 7ED

j.bezant@uwtsd.ac.uk

Kevin Grant

Archaeology, Room 322

Gregory Building

University of Glasgow

Lilybank Gardens

Glasgow

G12 8QQ

k.grant.2@ research.gla.ac.uk 


\section{The Post-Medieval Rural Landscape - toward a landscape archaeology? By JEMMA BEZANT and KEVIN GRANT}

SUMMARY: This paper examines the evidence for engagement with the rural post medieval landscape using two national case studies: Wales and Scotland. The issues reflected in these case studies are indicative of the wider challenges for archaeologists and professional practitioners alike. The paper recognises that landscape is not just about geographical place but an archaeological theoretical framework. It proposes that Post Medieval Archaeology monographs and conference sessions specific to landscape could help to tease out themes that address the big questions of the post medieval World: capitalism, modernity and Improvement, but also taking account of agency, identity and meaning. 


\section{INTRODUCTION}

Any attempt to consider the contribution of Post Medieval Archaeology (PMA) to the study of post-medieval rural landscape very quickly encounters a fairly serious difficulty - an almost complete lack of papers on this topic within the pages of this journal since its inception. This is a serious issue when we consider the significance of landscape in shaping our cultural and historical identities: it is indeed "the richest historical record that we possess". ${ }^{1}$ Lefebvre suggests that landscapes are spaces that are socially produced and that space serves "as a tool of thought and of action; that in addition to being a means of production it is also a means of control, and hence of domination, of power."2 In practice however, the study of rural landscapes "remain dominated by culture-historical approaches, and by methods that implicitly assume the primacy of documents." ${ }^{3}$ In addition, there are clear regional differences in the approaches to landscape. Drawing on two case study areas Scotland and Wales, this paper considers the role of PMA in shaping studies of post-medieval rural landscapes and reflects on how these landscapes are studied and interpreted differently to much of lowland England. In Scotland ${ }^{4}$ extensive bibliographies of two recent reviews of the study of post-medieval archaeology contain barely a handful of citations from PMA, while in Wales the journal has scarcely contributed to the key themes of study in contemporary scholarship. By necessity, this means that the authors have been forced to construct their case studies using material published elsewhere.

Although rural landscapes have not been a traditional focus of this journal, life in rural areas has been addressed through papers with what may be considered PMAs traditional focuses excavation reports and artefact studies, with only small number adopting an integrated 'landscape' approach. One example where excavation and material culture studies contribute to a landscape archaeology is Triggs, ${ }^{, 5}$ study of a $17^{\text {th }}-18^{\text {th }}$-century gentry estate in Bermuda. 
Triggs stresses the value of integrating as many archaeological sources as possible including artefact studies, environmental data, oral history and documentary history, and, critically, stratigraphic analysis as the correct way to develop a landscape archaeology which notes social, political and ideological analysis. The paper innovatively presents site plans, historic maps and digital elevation models alongside Harris matrices mapped against genealogical material. Despite the promise of this innovative and integrated approach, the opportunity is missed to contextualise 'place'. Not only is there no promised landscape reconstruction, there is little integration or landscape-oriented synthesis, which might combine to construct a landscape archaeology. Here are Fleming's ${ }^{6}$ 'muddy boots' in spades and excellently produced but there is none of Johnson' ${ }^{7}$ theorised and engaged historic landscape archaeology and history. Writing in PMA in 2011, Portocarrero ${ }^{8}$ used landscape as a methodology in which to reinterpret $16^{\text {th }}$ and $17^{\text {th }}$ century Portuguese coastal forts, placing power within a wider context in a way stimulated by the new castle studies of Johnson, Coulson, and Austin". Portocarrero critiqued traditional historiography's failure to "be critically aware of central issues of context and theory"10 and he went on to revise the existing dominant military interpretations. Although the cannon at Sao Domingo and Sao Pedro at Cape Espichel were "carefully pointed towards the sea", ${ }^{11}$ he noted that their particular arrangement within a small fishing harbour enabled them to dominate local maritime industries where the Crown had been complicit in reinforcing notions of 'the enemy'.

Concerned in 2005 with providing the SPMA with a research agenda for the "post-medieval agrarian society and landscape", Newman ${ }^{12}$ provided a comprehensive overview of the kind addressed in comparable research frameworks. ${ }^{13}$ He recognised that good landscape archaeology had advanced from a merely descriptive subject to a more critical and analytical 
one that placed sites within a context, provided techniques for analysing the social structuring of the environment and enabled a contribution to the environment of the individuals, communities, and different interest groups and classes. ${ }^{14}$ The opportunity to actually deploy this technique of critical analysis was missed however when he prescribed four main themes: archaeological science (dating, dendrochronology etc); the great estates and their impacts; regional surveys of farmsteads, and the excavation of farmsteads and their material culture. Nowhere was a theorised and critical analysis of method that accounted for socio-cultural themes that challenged a positivist, quantitative methodology.

These limited examples drawn from PMA highlight hint at two interesting issues - lack of a coherent sense of a landscape archaeology emerging from study of rural landscapes and a sense of archaeology failing to challenge and critique traditional historiographies. Both of these issues are highlighted in the following national studies. In the first, concerning the postmedieval landscape in Scotland, an account is given of the development of the sub-discipline, highlighting the key concepts and publications. For Wales, thematic case studies highlight the key themes of contemporary scholarship and the limitations inherent within largely untheorised cultural management processes are explored. The discussion and conclusion which follows the case studies considers why PMA has contributed so little to the study of rural landscapes in these areas, and considers future directions of study.

\section{NATIONAL STUDY - SCOTLAND'S POST-MEDIEVAL RURAL ARCHAEOLOGY}

Although always a small sub-discipline, Scottish post-medieval archaeology has established itself around a core of institutions and individuals as a distinctive area of study with distinctive questions, concerns, and interests. ${ }^{15}$ Since the subject's inception in the $1960 \mathrm{~s}$, it has been dominated by the study of rural Scotland, particularly of the Scottish Highlands ${ }^{16}$ - 
this focus has seen landscape emerge as a key concept. By outlining a brief history of the sub-discipline over the last half-century, and considering the subject as it stands today, the lack of contribution by PMA to understandings of the post-medieval Scottish landscape will be considered. Although reviews of the sub-discipline and of specific facets of it exist, ${ }^{17}$ this consideration has a particular focus on changes over the past decade and possible future directions of travel.

\section{POST-MEDIEVAL RURAL ARCHAEOLOGY IN SCOTLAND - A CONTEXTUAL}

\section{HISTORY}

Post-medieval rural life has been a feature of Scottish archaeology from its antiquarian beginnings - with the earliest papers on post-medieval rural settlement coming as early as the mid- $19^{\text {th }}$ century. ${ }^{18}$ Although the buildings and structures discussed in these papers were inuse in the $19^{\text {th }}$ century, they were not viewed as post-medieval archaeology. They were to be seen as prehistory. The rural landscape of the Highlands and Islands of Scotland were perceived as a living relic: a 'past in the present' where 'prehistoric' ways of living could be seen and observed in the present day. Thus these early papers conceived post-medieval rural life primarily as an important ethnographic parallel of Scotland's prehistory. ${ }^{19}$

In the early $20^{\text {th }}$ century, alongside antiquarian interest, life in rural Scotland became a focus of the emerging field of 'folk life' studies. ${ }^{20}$ Emerging from an earlier ethnographic tradition in the interwar period, ${ }^{21}$ folk life studies aimed to preserve surviving traditional practices which were perceived to be disappearing. At their most 'archaeological', these studies are highly descriptive and technical in character, with detailed drawings of material culture and descriptions of life in the past. Two seminal writers in this ethnographic movement, I. F. Grant ${ }^{22}$ and Alexander Fenton, ${ }^{23}$ were both instrumental in setting up centres of research on 
rural life. However, like earlier studies, Folk Life approaches often saw their material as timeless examples of an ancient way of life, despite being collected largely in the early $20^{\text {th }}$ century. In the same period, the School of Scottish Studies travelled the nation preserving the traditional cultural practices of Scottish life, particularly that of the rural Highlands and Islands, a tradition which is spiritually succeed in the field of Celtic and Gaelic Studies. ${ }^{24} \mathrm{~A}$ further parallel strand of post-medieval archaeology in Scotland is industrial archaeology. ${ }^{25}$ Emerging in the 1950s as a response to massive re-development and de-industrialisation, industrial archaeology was driven forward by a small number of individuals outside of archaeology who until recently remained largely isolated from wider post-medieval archaeology and the discipline as a whole. ${ }^{26}$ Although not directly relevant to rural archaeology, these studies ran in parallel to the development of post-medieval archaeology as a subject of study and, as will be discussed in this paper, have shaped and influenced it.

The modern archaeological study of post-medieval rural Scotland began at the University of Glasgow, which remains at the centre of historical Scottish archaeology today. ${ }^{27}$ A year before founding the department of archaeology ${ }^{28}$, historical geographer Horace Fairhurst published a paper outlining the general characteristics of the Scottish rural landscape, both Highland and Lowland. ${ }^{29}$ In contrast with antiquarian approaches of the previous generation, Fairhurst recognised that the rural landscapes of the $18^{\text {th }}$ century, far from being timeless prehistoric survivals, were probably fairly recent in character but had essentially been projected, without evidence, into the distant past. ${ }^{30}$ This re-interpretation of the evidence of rural landscape revealed a gap in knowledge that spanned from the Iron Age until the $18^{\text {th }}$ century. Attempting to understand these 'missing centuries' was a major focus of postmedieval and medieval archaeology for the next four decades. ${ }^{31}$ The very first issue of PMA contained a paper on rural Scottish archaeology that reflected these concerns. In 'the divide 
between medieval and post-medieval in Scotland', Crawford ${ }^{32}$ outlined the problem of the 'missing centuries' and sought to situate the issue of separating the post-medieval and medieval periods in Scotland historically. In theoretical terms Crawford's paper is a textbook example of its day. Drawing on the work of Childe, Crawford suggested that Scotland was an example of 'the Systadial Problem - the disparity between the economies of developed and under-developed continents and regions at the same and different periods, ${ }^{33}$ Although very much dated by today's standards, the article is laudable in that it considered Scottish rural archaeology within an explicit theoretical framework, and reflects the wider conceptual concerns of the subject area - something that has rarely occurred since in PMA.

The sub-discipline that Fairhurst founded, and which was later pushed forward by many of his students, ${ }^{34}$ was known as Scottish Rural Settlement Studies. Later, this subject area came to be known as Medieval or Later Rural Settlement (MoLRS) in recognition that the character of rural settlement in the early and later medieval period was (and is) largely unknown. ${ }^{35}$ The sub-discipline was from its very beginnings, and perhaps as a result of Fairhurst's background in human geography, concerned with landscape and settlement patterns. This focus on landscape was further influenced by the work of the Royal Commission on the Ancient and Historical Monuments of Scotland (RCAHMS), who had been recording extensive post-medieval remains in the landscape since the original 'cut-off' date of 1707 was rescinded in $1948 .^{36}$ From the 1990s onwards, RCAHMS surveys included extensive recording of post-medieval buildings as well as specific projects focusing on these aspects of the Scottish landscape. ${ }^{37} \mathrm{~A}$ focus on landscape and settlement patterns - with a particular focus on how these landscapes changed over time ${ }^{38}$ characterises much of this work. 
In the early 1990s, an advisory group was set up by Historic Scotland on its policy toward post-medieval rural archaeology. ${ }^{39}$ From this process emerged the MoLRS working group, later the Historic Rural Settlement Group, who produced several significant outputs in the subject area. In terms of published work, a retrospective on the previous decade of the study of rural landscapes in Scotland provided a welcome output for varied research ${ }^{40}$ whilst an edited volume on rural settlement in Scotland, England, and Wales linked recent work into the wider sub-discipline across the United Kingdom. ${ }^{41}$ This interdisciplinary group were also deeply involved in what was probably the largest and most significant archaeological examination of the Scottish rural landscape - the Ben Lawers Historic Landscape Project. Unfortunately, apart from a few papers ${ }^{42}$ and grey literature ${ }^{43}$ this project remains unpublished. A further output of the group was Scotland's Rural Past, a multi-million pound community archaeology project that aimed to research, record, and promote rural settlements and landscapes. ${ }^{44}$ The body of work produced largely as a result of the the Historic Rural Settlement Group has resulted in a significant increase in primary data concerning the Scottish post-medieval landscape. However, the changes in the theoretical underpinnings of the discipline since 2000 are equally significant.

\section{POST-MEDIEVAL RURAL ARCHAEOLOGY IN SCOTLAND - THE $21^{\text {ST }}$ CENTURY}

In theoretical terms, the study of the post-medieval rural landscape in Scotland in the $20^{\text {th }}$ century was dominated by empirical approaches. The recording work of RCAHMS ${ }^{45}$ was perceived to an 'inventory' and essentially 'atheoretical'. Earlier research-focussed work had often centred around attempting to find evidence for the 'missing centuries', 46 and many excavation reports by commercial units tended to be largely descriptive. ${ }^{47}$ Due to an apparent reluctance to engage with theoretical developments within the wider discipline of archaeology, the study of the post-medieval Highlands has often lacked theoretical rigour, 
confidence, and maturity. This was the case when the last review of the subject area took place, ${ }^{48}$ although even then, a more theoretically rigorous and outward looking post-medieval Scottish rural archaeology was emerging. ${ }^{49}$

The 2000 volume Townships to Farmsteads ${ }^{50}$ brought together an impressive array of informative papers from a number of disciplines across the UK. Until around 2000 the study of the Highlands and Islands had tended to be somewhat inward-looking, cut off from the post-processual movement which had been in full swing in wider archaeology for over a decade. ${ }^{51}$ Three papers in particular in that volume represent more outward-looking and theoretically contextualised approaches to the rural highland landscape.

\section{LANDSCAPE, THEORY, AND THE INTERNATIONAL OUTLOOK}

The first of these is 'The Prospect of the Sea', ${ }^{52}$ an evocative paper, it is all the more striking given its distinctiveness within the volume. In this paper Lelong sought to examine the cognitive and experiential aspects of landscape by considering the experience of Highlanders cleared from the inland world of Strathnaver, Sutherland, to the seascape of Scotland's north coast. Although the paper draws primarily from historical sources, there are clear influences from post-processual archaeology - the many descriptions of the tactile experience of moving and inhabiting the landscape and the relationship between landscape and people are distinctly phenomenological in character. Discussions of routine practice and the marks and inscriptions these practices leave on the land draw to mind the theory of taskscape. ${ }^{53}$ Despite these obvious post-processual influences, the paper is striking for its lack of any overt discussion of theory - a single oblique reference to Tilley ${ }^{54}$ is the only suggestion of the theoretical underpinnings of the paper. This is, perhaps, an example of the 'epistemological timidity’ described by Campbell ${ }^{55}$ - Lelong, writing in a volume dominated by empirical and 
descriptive approaches, declined to overtly display the theoretical underpinnings of her approach.

The work of Dalglish ${ }^{56}$ drew more confidently on post-processual approaches to landscape ${ }^{57}$ and theoretical approaches from wider international post-medieval archaeology. ${ }^{58}$ Dalglish used this wider theory to draw together landscape archaeology, historical research, considerations of cultural traditions, and later architectural analysis, ${ }^{59}$ in a striking study of the Scottish rural landscape as an example of the global phenomenon of the emergence of capitalism. ${ }^{60}$ In 2004, Given used examples from the Highland post-medieval landscape in 'the Archaeology of the Colonized', 61 a text which sought to examine aspects of the archaeology of colonialism. It included examples ranging from $18^{\text {th }}$-century Loch Lomond, Bronze Age Cyprus, and Nazi Germany. The work of Adamson, coming from an industrial archaeology background $^{62}$ used examples of commercial activity in the rural Highlands to consider wider questions about commercialisation, capitalism, and improvement. ${ }^{63}$ In these works, all emerging from University of Glasgow, the post-medieval rural landscape is not simply an object of study for its own sake - it is considered as part of international processes that were occurring across the post-medieval world. This outward-looking and internationalist view of the rural landscape, supported by the underpinnings of postprocessual and landscape archaeology, defines the approach to historical archaeology which has developed in Glasgow since the turn of the century. ${ }^{64}$

\section{FOLK-LORE, MATERIAL CULTURE, AND LANDSCAPE}

The second paper in 'Townships to Farmsteads', 'the Dark Island Revisited', 65 is emblematic of a tradition in the study of rural landscape in Scotland which integrates folk lore, material culture, and landscape archaeology approaches. Symonds draws on work in the 1990s as part 
of the Sheffield Environmental and Archaeological Research Campaign in the Hebrides $(\mathrm{SEARCH})$ project $^{66}$ to put forward the case for a 'historical ethnography', drawing on postprocessual theory, such as Bourdieu, Bender, Tilley, and Ingold ${ }^{67}$ folklore approaches, ${ }^{68}$ and the classic material culture studies of North American Historical Archaeology. ${ }^{69}$ This approach represents a reconnection between the fields of folk life, folk lore, Scottish Gaelic and Celtic Studies, and theoretically mature, international, post-medieval landscape archaeology. Earlier considerations of material culture ${ }^{70}$ and later considerations of the role of vernacular architecture ${ }^{71}$ also arguably belong to this tradition of presenting tactile and experiential understandings of landscape imbued with cultural and symbolic meaning.

This coming-together of multiple ways of considering rural Scotland, underpinned by contemporary post-medieval and landscape archaeology theory, was strangely short lived. This can perhaps be explained by the end of the SEARCH project, which had brought together archaeologists with a range of contemporary theoretical approaches from different periods in an extended study of a rural island landscape. Whilst the project is currently being published, ${ }^{72}$ these works comprise monographs in which the content is, although theoretically situated, largely descriptive. A recent revisiting of these approaches ${ }^{73}$ precedes doctoral research that will draw on this inter-disciplinary approach to landscape to consider the practice of post-medieval landscape archaeology in Scotland and its relationship to wider narratives of modern Scottish history. ${ }^{74}$

\section{LOCAL DISTINCTIVENESS, INTERNATIONAL SIGNIFICANCE}

The final paper in the volume ${ }^{75}$ considers what post-medieval archaeology means for presentday ideas of identity and memory. ${ }^{76}$ In it, Basu sought to consider the rural landscape of Sutherland - in particular, how its famous narrative of clearance makes it a site of cultural 
memory and identity. In many ways, this paper is a response to circumstances that are peculiarly Scottish. The study of Scotland's history and archaeology has been fundamentally shaped by ideas about identity, often constructed from $19^{\text {th }}$ century romantic traditions. ${ }^{77}$ Additionally, aspects of the character of the landscape and its use, such as crofting, are unique to Scotland. ${ }^{78}$ These factors have often resulted in an inward-looking view of the past which has over-emphasised Highland and Gaelic landscapes and culture, a widespread interest in what are perceived to be distinctively 'Scottish' or 'Celtic' topics, and a strong influence from highly romanticised aspects of Scottish historiography. ${ }^{79}$

Basu, ${ }^{80}$ in explicitly highlighting these inward-looking influences and considering how archaeology creates and is shaped by identity and memory, is a good example of a move in post-medieval Scottish archaeology to recognize that Scottish engagement in the wider world in the Modern period was not "fundamentally and entirely different" to that of other nations. ${ }^{81}$ This movement then has sought to place Scottish post-medieval archaeology within the wider international world of Historical Archaeology. A further response has been to consider how uniquely Scottish perspectives, which often relate to contemporary Scottish politics, ${ }^{82}$ can be understood as more widely significant to archaeology and contemporary society. In this sense, post-medieval archaeology in Scotland, with its particular emphasis on rural landscape, is used to inform much wider understandings of how archaeology and landscape create identity and shape the contemporary world. ${ }^{83}$

\section{SPMA AND THE SCOTTISH RURAL LANDSCAPE}

Since the first edition of PMA, there has been striking lack of papers concerning Scotland at all. It is difficult to say whether this reflects a perception of PMA as Anglo-centric or it something in the nature of Scottish archaeology, which occupies 'an ambiguous position with 
the wider historical archaeology of Anglophone countries' ${ }^{84}$ Papers on Scottish archaeology as a whole, including post-medieval and rural archaeology, tend to be published in the Proceedings of the Society of Antiquaries of Scotland, the Scottish Archaeological Journal and elsewhere - but this should not be taken to suggest it is entirely insular, as the International Journal of Historical Archaeology has been host to many significant papers in the subject area. Of those papers on Scottish subjects which have appeared in PMA, almost all might be considered 'industrial archaeology'. ${ }^{85}$ These are generally excavation reports or highly technical papers with varying degrees of theoretical rigour and engagement with wider issues in the post-medieval world.

Three recent papers deal with the rural Scottish landscape, but all somewhat peripherally. Dalglish's ${ }^{86}$ paper considers Scottish castle architecture in the $16^{\text {th }}$ and $17^{\text {th }}$ centuriesin the 'age of transition' between medieval and post-medieval, placing them in their landscape context. 2014 saw the publication of a comparative study of rural Virginian and Scottish material culture which drew on processual approaches and the archaeology of capitalism to consider commodification analysis and its utility in understanding colonial consumerism. ${ }^{87}$ Barrowman's ${ }^{88}$ recent paper, building on evidence from excavation, considers an unusual island stronghold site in Lewis within the much wider context of Scottish and Gaelic power structures in the post-medieval period. All these recent papers are theoretically and contextually situated contributions to the study of rural Scotland, but they have tended to approach the topic through what are perhaps PMA's traditional foci - material culture, architecture, and excavation reports. What appears to be missing, is landscape. 
Post-medieval archaeology in Wales has principally been driven by historical investigations of the industrialised coal and ore measures of the south and the slate measures of the north, and, quite rightly, as they represent some of the World's best of their type. Despite this industrial emphasis it is the rural landscape that is often most strongly linked to language, culture, Welsh identity and a sense of place. These issues relating to rural history were pursued by Iorwerth Cyfeiliog Peate in the 1940s who deliberately shaped a folk culture based on material culture and vernacular architecture of the kind seen in the scattered rural farm-scapes of 'upland' Wales. Along with Sir Cyril Fox, he founded the Welsh Folk Museum at St Fagan's, now the St Fagan's National History Museum, part of the National Museum of Wales. It opened in 1948 with Peate as its first curator. His The Welsh House: A Study in Folk Culture ${ }^{89}$ was more than simply a study of rural vernacular architecture, drawing also on cultural identity as an explanation for architectural form. Peate referred to the medieval Welsh Law codes when examining the ancient dwelling and lists of building materials allowed him to link traditional materials and methods to cultural aspects of the gwerin or folk and their homes. Peate describes an Irish Neolithic 'house', divided into a long central space with 'side aisles' or sleeping compartments. These were linked by him to the Welsh peasant ty hir or longhouse as a way of establishing great antiquity in the 'Celtic' building traditions of Western Europe. Aileen Fox's ${ }^{90}$ excavation of upland house platforms at Gelligaer Common in Glamorgan during the 1930s revealed that dwellings had a large central post-hole with another at one end behind the hearth leading her to infer a poor, lowstatus construction of non-cruck type. Fox placed the buildings in the context of an upland Welshry in clear contrast to the sophisticated lowland Englishry nearby. These upland remote settlements appeared to represent a survival of territories based upon kinship and custom which were essentially determined by a terrain ideal for native, small-scale pastoral agricultures. In 1962 Lawrence Butler ${ }^{91}$ excavated the interior of a hut platform at Bwlch yr 
Hendre an area under threat due to a new hydro-electric scheme in the upper Rheidol valley. Bwlch yr Hendre appeared to predate $18^{\text {th }}$ century settlements along the Camddwr valley and Butler considered the wider anthropogenic effects on the landscape of peat cutting, mining and droving. For Butler, however, the lack of material culture seemed to support the hut's use as a simple hafoty or 'summer house', of the type described by Sayce ${ }^{92}$ a seasonallyoccupied dwelling as part of a transhumant economy. The excavation and dating of 'native' structures and their relevance and association to the wider landscape has barely moved on since Butler's fieldwork but surveys on the Black Mountains in Carmarthenshire by Ward ${ }^{93}$ have demonstrated the potential for future archaeological excavation. Successful excavations ${ }^{94}$ yielded rich $15^{\text {th }}-16^{\text {th }}$ century deposits at the upland site of Hafod y Nant Criafolen in Clwyd where the unexpectedly rich remains have challenged the primitive and ephemeral nature of these upland sites. Stone-built structures, outhouses and middens also revealed pottery, spindle whorls, whetstones, decorated bake stones and scourers, worked bone scoops, horse shoes and nails, and an iron sword dated occupation to the $15^{\text {th }}$ and $16^{\text {th }}$ centuries. Apart from the brief glimpses noted above, the acute historical lacunae plus limited archaeological excavation has not allowed landscape to be investigated in any meaningful way. This provides us with little fuel with which to challenge dominant narratives about 'the poor' or peasant folk culture, or to move us on from mere cultural historical record.

\section{POST MEDIEVAL RURAL LANDSCAPE IN WALES: THE $21^{\text {ST }}$ CENTURY}

\section{ENCLOSURE, IMPROVEMENT AND THE UPLANDS}

Writing about the later historical period, Tarlow ${ }^{95}$ warns that "the 'superficial familiarity' of the period often masks what is historically distinctive about the modern age". She contests that the social significance of Improvement might have lain more in the creation of new "horizontal relationships of belonging than with hierarchical and exclusive relations of 
dominance". ${ }^{96}$ Investigating the abandoned 'squatter' settlement at Rhosgelligron in central Ceredigion, Tarlow ${ }^{97}$ notes the social unrest generated by the accelerating pace of enclosure. These modest cottages of the rural poor were constructed during the $18^{\text {th }}$ and $19^{\text {th }}$ centuries on the fringes of common land at the liminal junction between the agriculturally enclosed and occupied lowland and the unenclosed mountain sheepwalks of the Cambrians. The stone-built one or two celled cottages accompanied by modest outbuildings and a small garden plot lay scattered across the boggy common. Settlements such as this were undoubtedly considered squalid, rude and illegal and were the target of attempted evictions, particularly where the owner was the Crown or one of the gentry estates. This was the case on part of the Trawscoed estate at Cnwc Coch near Aberystwyth where the 'miserable huts' spoiled Colonel Vaughan's view from his plas. Despite this, parts of the Rhosgelligron 'squatter' settlement prospered into the later $19^{\text {th }}$ century with around twenty dwellings on the site with many acquiring brick lined windows, proper chimneys and staircases leading to a second storey. The precise trajectory from late medieval farmstead to the phenomenon of 'squatting' on adjacent land is still poorly understood however and we should challenge simplistic explanations concerning population rise and the lure of the industrialised south. Much is made of the 'traditional' and common rights of the 'squatter' having the right to erect a dwelling overnight - a Ty Unnos a one night house. Common land is rare in Ceredigion comprising only a small part of a suite of resources available to the surrounding tenant farms which included rich wetlands, fertile arable floodplain and enclosed 'in-fields' for sheep and cattle husbandry. By far the most valuable agricultural resource was the distant and unenclosed sheepwalk located on the mountain uplands and access to this was maintained through the traditional payment of the commorth even into the later post-medieval period. ${ }^{98}$ Tarlow sought to challenge the perceived lowly status of such a community. They were well educated with some described as scholars, and collectively they constructed a Calvinistic Methodist Chapel to administer to 
the whole community. ${ }^{99}$ It is difficult to detect rights and status in the poor historical record and, what was termed illegal squatting by an absentee landlord, may have been simply a reinterpretation of hereditary rights of access onto shared land by the tenants themselves - a physical occupation in the form of a dwelling replacing the periodic use and reuse of the land's resources.

These neo-marxist interpretations of status allow us a useful revisionist understanding of rural inhabitants. Although Tarlow ${ }^{100}$ makes the point that enclosure was part of an ideology that had influence over architectural space and other material practice, the precise context of landscape and agency of individuals within those wider spaces deserves further investigation. Wmffre's approach considers an active landscape populated with individuals discerned from the historical record. As a socio-linguist and a Welsh language expert, he uses place names and historic records to reconstruct land-use and tenurial patterns. Combining this with field visits and oral testimony he produced a remarkably detailed and nuanced account of the practice of sheepwalks or liberts of upland grazing in the Doethie Valley in the Ceredigion Cambrian Mountains ${ }^{101}$. A detailed and useful study, one can't help but note that the opportunity to examine really meaningful socio-cultural nature of upland settlement and sense of place has been left unexplored here.

There is a sense of the nature of Welsh identity behind Sambrook's work on the Cadwfunded Deserted Rural Settlements report. ${ }^{102}$ This volume assembles a comprehensive collection of papers based on audits of the archaeological potential of, mainly upland, deserted settlements which was undertaken by the four individual Welsh Trusts. ${ }^{103}$ Sambrook's chapter contains a detailed section examining the phenomenon of the lluest in the $18^{\text {th }}$ century Crown Manor of Perfedd in Ceredigion. Originally codified in the $10^{\text {th }}$ 
century, law codes ${ }^{104}$ described a lluest as a temporary camp or hut. By the $17^{\text {th }}$ century this meaning had become associated specifically with sheep grazing in the upland Cambrians of central Wales. Sambrook goes on to note later abandonment of this practice. ${ }^{105}$ From 48 lluestau in 1744, only 13 remained by 1794 , and these in the most sheltered and most accessible locations. This is explained in terms of either climatic, economic or agrarian factors, or the lure of employment in the south. ${ }^{106}$ The quadrupling of the population between 1563 and 1670 in Eglwyswrw in Pembrokeshire provides Sambrook with a potential date horizon for much of the apparently new settlement and building in the area. For Sambrook, poor equals poorly built and he notes the limited chances and opportunities that meant landless poor were driven to squat on roadsides and marginal land. As we saw at Rhosgelligron, this was encroachment and regarded as illegal activity. ${ }^{107}$ Though Sambrook expresses caution in the interpretation of historic evidence, we should really interrogate in much more detail, the ways that archaeological evidence for assumptions such as upland abandonment and the Great Rebuilding are linked to the usual explanations around environmental and economic drivers. Johnson ${ }^{108}$ proposes that these kinds of 'landscape reconstructions' are inadequate and mundane while Fleming defines this traditional approach as preferring "space to place, and territory to tenure". ${ }^{109}$ Austin challenges these kinds of assumptions in his reflections on the audit-driven Deserted Rural Settlements project ${ }^{110}$ and he describes the need for more intellectual and emotional ownership of the places within Welsh rural landscapes. ${ }^{111}$ He points out that individuals are often ignored or relegated to actors within a system rather than agents of it.

CURATION AND MANAGEMENT OF POST-MEDIEVAL RURAL LANDSCAPES IN WALES 
Despite occasional illuminating glimpses of research such as that discussed above, much of the engagement, management and investigation of Wales' rural landscapes is facilitated through a number of statutory bodies concerned with development control. $\mathrm{Cadw}^{112}$ is the Welsh government's historic environment service and performs a similar service to Historic Scotland and the newly-formed Historic England. It would be fair to say that post-medieval landscapes are largely managed and curated in Wales through a number of superficially robust regulatory structures that afford developers and archaeologists a false sense of security. Austin ${ }^{113}$ explores Historic Landscape Characterisation (HLC) for an historic landscape in south Wales. This debate acts as a concluding discussion in a volume of Landscapes given entirely to debating HLC by a number of contributors. Rippon ${ }^{114}$ notes the origins of HLC in the way that Rackham fused history, historical geography and historical botany to map ancient and planned landscapes across Britain. At the same time, the 'dots on a map' approach to curation of individual, unconnected sites began to change and whole landscapes were recognised to have particular historical significance.

Austin's ${ }^{115}$ concerns with this process that he saw as somewhat reductive were that:

- it was easy to create simple and convincing patterns from complex data, but almost impossible to create complex ones

- the process of change itself is seldom examined in a sustained way

- and that dating is difficult and should be suspected on morphological and typographical forms alone.

Austin acknowledged that whilst these management systems have at least placed landscape right into the heart of development control they have somehow failed to grasp the point of studying landscape in a meaningful and connected way. He ponders why we are somehow still content to use objective morphological classifications administered by GIS (geographical 
information systems) for instance, "where we should have been thinking about complexity, narrative and contingency, the 'brightly coloured mask' of bounded space offered us false certainty and authority". 116

The archaeological desk based assessment in advance of a major housing development in South Sebastopol, Torfaen, Glamorgan recorded a rural farmscape; rare in this heavily industrialised area of South Wales. Austin demonstrated that the assessment failed to recognise the unmapped features of changing socio-economic activities - earthworks, lynchets, ridge and furrow for instance. The investigation relied heavily on LANDMAP, a GIS-driven process curated by the now defunct Countryside Council for Wales. ${ }^{117}$ LANDMAP is a non-statutory system designed to assist decision making for development control and landscape management generally. It supplies a number of themed GIS layers including geology, habitat, cultural, visual and sensory and historic value. Austin was highly critical of the process that allowed planners to assign a 'moderate' historic landscape value to the two farms in question; Maesgwyn and Tr-Brychiad. By visiting and observing the development area he was able to examine the farms in their wider landscape context and challenged the LANDMAP process that had allowed the arbitrary separation of lowland and upland essentially decontextualising contingent parts of the landscape whole. ${ }^{118}$ While it was recognised that the area contained 'surviving post-medieval valley-bottom farmland, ${ }^{119}$ Austin was able to establish greater time depth and he identified relict enclosures and house platforms, pushing the chronology of the site back into the later medieval period.

For Austin, GIS- based, top-down management processes had flattened out complexity within the landscape and failed to be critical about change and date. They had failed to acknowledge 
that "the marks of the past in the landscape that appear on maps and are given great prominence by the cartographer such as field boundaries are as much the result of conflict or competition as harmony". ${ }^{120}$ They had conveyed a false sense of 'academic' certainty - a kind of meta-narrative that created false authority, denying communities and other audiences their voices. These quantitative management systems ignore the continuing processes of alternative narrative which lie at the heart of all communities - they reduce landscape to caricature. $^{121}$

While it remains to be seen whether only academics can make a meaningful contribution to rural landscape studies, it is clear that engagement by both archaeological practitioners and communities together produce successful results. The Strata Florida Project ${ }^{122}$ in mid Wales is very much engaged with its community and is studying the long history based on the vast Cistercian holdings of one of Britain's largest monastic estates - from the later Iron Age onwards up to the present day. This is a multi-disciplinary project engaging archaeology, history, environmental science and the arts and has involved a number of institutions including the Monastic Wales Project, Sculpture Cymru, the Royal Commission on Ancient and Historic Monuments in Wales (RCAHMW) and the Centre for Advanced Welsh and Celtic Studies. This broad scale approach is time-consuming and dependent on many hours of field survey, excavation and historical toil. The Shapwick Project ${ }^{123}$ drew heavily on community involvement which allowed the production of a thick description of the parish in east Dorset, southern England. These types of projects- in and of their communities do much to write and revise useful landscape histories in rural areas that are largely investigated only in advance of developments such as renewables and large scale energy projects. Management processes need to do much more to engage with and address local and regional narrative and to actually integrate narrative into management systems. 


\section{DISCUSSION AND CONCLUSION}

\section{IMPROVEMENT AND MODERNITY}

Some striking similarities can be drawn from the two national case study areas. It is clear that the study of the upland landscapes of our study areas is fundamentally different in approach to that of the 'champion' English lowlands. The impact of early folk life studies is clear to see and appears to have had much less influence on archaeology in England. It may be that England has its own distinctive processes of establishing narratives around identity and nationality that have shaped its archaeology in different ways to the case studies given here. However, we should of course avoid stark distinctions. Fleming's ${ }^{124}$ consideration of Swaledale in Yorkshire takes a thematic rather than chronological approach and talks about the longevity of estates or 'folk territories'. Another key theme is, perhaps unsurprisingly, Improvement. In both case studies, Improvement and change have been a key part of wider discussions about the emergence 'modern' ideas and ways of being- such as the emergence of capitalism and changing social structures. Domestic architecture, materiality, and many aspects of every-day practice have also contributed to discussions about these wider concepts. Despite occasional engagement with these wides issues, in both case studies it is suggested that most of the work on rural landscapes has been empirical in character and disconnected from these wider concerns.

Tarlow ${ }^{125}$ indicated in 2007 that it was "no longer necessary to lament the rudimentary state of archaeology of later periods in Britain”. She noted that by 2003 there were as many as seventeen positions in British archaeology departments where staff identified this later period as an area of interest. It was no longer correct, she argued, to say that the period is neglected. 
But she does point out the theoretical constraints within which many in this area work - they 'do not contextualise their work beyond questions of local technological and economic development, or the narrow histories of one kind of material...there is little sense that arguments are being made". ${ }^{126}$ Within the traditional foci of PMA such as field archaeology and artefact-centred research, Tarlow ${ }^{127}$ lists the 'big questions' that are still having limited impact here; capitalism, class identity, modernity, industrial society (rather than industrial machinery), the variety and nature of personal and group identities, colonial and post-colonial relations, and economics and the development of modern consumerism. The list is long and embarrassing - the rural landscape is writ large with these themes.

In both Scotland and Wales, recent research frameworks have attempted to address these issues. In Scotland, possible future directions in post-medieval archaeology are suggested in the Scottish Archaeological Research Framework (ScARF). The 'Modern' panel, which covers the post-medieval period, sets out an ambitious stall - where previous approaches to the post-medieval period in Scotland might be accused of tinkering away at the edges of preexisting historical narratives, ScARF engaged with topics which are fundamental to the nature of life and society in the modern period. ${ }^{128}$ Following a conference arranged by the IfA Wales/Cymru in 2001, the Research Framework for the Archaeology of Wales (RFAW) emerged after consultation with a number of stakeholders. It was devised to provide an assessment/audit from which an agenda and research strategy could be framed. This remains an ongoing, iterative process and meetings and updates on assessments and bibliographies are available online. ${ }^{129}$ One of the fundamental issues already identified is that there is "no clear intellectual starting point for approaches to the period". ${ }^{130}$ In both cases, the panels steer clear of the term 'post-medieval' ${ }^{131}$ preferring Modern and Early Modern. In Wales, it is notable that the post-medieval is considered to suffer from a lack of cache or "emotive 
appeal" of the medieval period. ${ }^{132}$ This is an interesting difference with Scotland, where the study of the later medieval is greatly lacking, perhaps partly because it is overshadowed by the high resonance of the post-medieval period in the Scottish public imagination - issues such as clearance, land reform, and identity loom large in contemporary political discourse. This connection to issues in the contemporary world is mirrored in Wales where the curation of the post-medieval landscape is tied up with complex ideas about agricultural management, 're-wilding, ${ }^{133}$ and Welsh identity. While the rural landscape may not feature heavily in PMA, it is clear that in Scotland and Wales at least issues to do with the post-medieval landscape are an important part of contemporary attitudes toward landscape and society.

\section{CHALLENGING HISTORICAL META-NARRATIVES}

Another theme which emerges is the dominance of historical narratives and a failure of archaeologists studying the post-medieval to effectively challenge these. In Wales, Austin ${ }^{134}$ ascertains that successful narratives about the post-medieval landscape have been driven primarily by historians, who mostly ignore the archaeological evidence. The blame for this is laid at the feet of the archaeologists who have failed to make a clear contribution with the result that interdisciplinary themes often end up with two different but parallel narratives. He implores us to look again at 'neat' models of transhumance for instance (the hafod/hendre mode ${ }^{135}$ ), to avoid reducing the socio-economic system to absurd simplicity. ${ }^{136}$ In Scotland, it was recognised as early as $1988^{137}$ that the study of the period was largely sub-servient to existing historical meta-narratives. As a result, archaeology in the post-medieval rural landscape often simply illustrated these, while its role in producing history can be 'extremely limited.' ${ }^{138}$ This apparent lack of confidence on the part of archaeology to challenge an extensive historical literature ${ }^{139}$ has been termed an 'epistemological timidity. ${ }^{, 140}$ This failure may in large part be as a result of a lack of appropriate theoretical approaches to the period - 
if, as Tarlow ${ }^{141}$ suggests, there "is little sense that arguments are being made" it is no surprise that archaeologists are failing to engage with the topic on a par with their colleagues in history.

\section{LANDSCAPE}

One key concept which emerged from both case studies is that of landscape. In Wales, landscape has often been obscured by unsophisticated management processes such as LANDMAP and HLC. The themed audits deployed by Cadw provide vital data in areas where we previously knew little but do nothing to provide narratives about place and meaning. It is vital that we actually practice theoretically the situated methodologies prescribed by academics and professional practitioners alike so that later landscapes can be recognised and valued by planners and developers. We know we should account for language, identity, and agency if we are to write meaningful landscape narrative but this is absent from methodologies of curation and protection. As suggested in the case study of the post-medieval rural Scotland, over the past two decades it has often been the shared language of landscape that has brought together disparate disciplines and traditions to create nuanced and theoretically rigorous considerations of the topic. Starting in the 1990s, the sub-discipline began to reach outwards - joining the international community of historical archaeology and understanding the Scottish landscape in terms of global trends. At the same time, many disparate strands of the study of the rural landscape such as, folk lore, folk life, and industrial archaeology have begun to enter archaeological discussions about the recent past in the rural parts of Scotland. Often, landscape archaeology and its associated theory has formed the basis of these discussions, drawing in international and multi-disciplinary approaches under the umbrella of a shared theoretical language. 
The SCARF modern panel theme 'People and Landscape' regards landscape as 'a particular avenue into questions of self and society in modern Scotland' ${ }^{142}$ The introduction to the landscape theme suggests that there are three broad conceptualisations of landscape: as the physical land itself; as a matter of perception and meaning; and as a matter of experience and relationships. ${ }^{143}$ Arguably, considerations of the rural landscape in PMA fall largely into the first category, empirical and descriptive accounts of archaeological features, objects, and structures which are on the land, not of the landscape. Although PMA as a whole perhaps publishes papers which are more empirical, technical, or descriptive in character than other journals covering a similar period such as Historical Archaeology or the International Journal of Historical Archaeology, the SPMA monographs since $2002^{144}$ have certainly shown that there is a stimulating, theoretically involved, and outward-looking character to the society and its members which is not well-reflected in PMA. It is notable that as yet none of these monographs have had a focus on landscape, or indeed the rural landscape. It may be that such a monograph would stimulate discussion and encourage such approaches to appear more frequently in the pages of PMA.

If we wish to begin to understand the post-medieval landscape, and what it means for the fundamental questions of life, society, and experience in the post-medieval period, our methodologies must be clearly theoretically situated. Although there are likely to be many appropriate theoretical approaches to the topic, landscape may hold the promise of bringing an international, inter-disciplinary, and theoretically vibrant and rigorous approach to the subject. It is hoped that by engaging with these developments more fully, PMA can contribute more to the understanding of post-medieval rural life and landscape in the next 50 years than it has in the last. 


\section{ACKNOWLEDGEMENTS}

The authors would like to thanks the kind review comments and suggestions of Professor

Charles Orser and Dr David Petts. Errors and omissions are the authors' own.

\section{BIBLIOGRAPHY}

Adamson, D. B. 2008, "A coal mine in the sea: Culross and the Moat Pit". Scottish Archaeol. Journ. 30, 161-199.

Adamson, D. B. 2014, Commercialisation, change and continuity: an archaeological study of rural commercial practice in the Scottish Highlands. (PhD), University of Glasgow, Glasgow.

Allen, D. 1979, 'Excavations at Hafod y Nant Criafolen, Brenig Valley, Clwyd, 1973-74', Post-Med. Archaeol. 13, 1-59.

Aston, M. \& Gerrard, C. 2013 Interpreting the English Village: Landscape and Community at Shapwick, Somerset, Oxford: Windgather Press.

Atkinson, D. 2012, 'The Leamington Scow: the excavation of historic structures and canal vessel at Leaminton Wharf, Union Canal, Edinburgh'. Post-Med. Archaeol. 46 (2), 229-251.

Atkinson, J. 2000, 'Rural settlement in Lochtayside: understanding the landscapes of change'. In J. Atkinson, I. Banks \& G. MacGregor (eds) 2000.

Atkinson, J., Banks, I., \& MacGregor, G. (eds) 2000, Townships to Farmsteads: Rural Settlement Studies in Scotland, England, and Wales. Oxford: British Archaeological Reports.

Atkinson, J., Dalglish, C., Lelong, O., MacGregor, G., \& Shearer, I. (2005), Ben Lawers Historic Landscape Project: Excavations at Tombreck and Kiltyrie. Glasgow: GUARD.

Austin, D. 1984, 'The castle and the landscape', Landscape Hist. 6, 69-81

Austin, D. 2006, 'The future: Discourse, objectives and directions', in Roberts 2006, 193-206.

Austin, D, 2007, 'Character or Caricature? Concluding Discussion', Landscapes, 8:2, 92-105.

Austin, D. 2012, 'An aura of hiraeth - Strata Florida', pp. 51-58 in Bowen, H. Buildings and Places in Welsh History, Gomer Press. 
Austin, D. 2013 'Mountain landscapes and the tradition of industry: the Cambrian Mountains of Central Wales' MADE, Journ. of the Welsh School of Archit. 8, 6-15

Ballin, T. B. 2012, "State of the Art' of British gunflint research, with special focus on the early gunflint workhsop at Dun Eistean, Lewis'. Post-Med. Archaeol. 46 (1).

Barrowman, R. 2015, 'A local response to a wider situation: the archaeology of the clan stronghold of Dùn Èistean, Isle of Lewis '. Post-Med. Archaeol. 49 (1), 37-56.

Basu, P. 2000, Sites of Memory/Sources of Identity: Landscape-Narratives of the Sutherland Clearances. Oxford: British Archaeological Reports.

Bezant, J. 2014, 'Revising the monastic 'grange': Problems at the edge of the Cistercian world', Journ. of Med. Monast. Stud. 3, 51-70.

Bezant, J. 2013 'The medieval grants to Strata Florida Abbey: mapping the agency of lordship', in Burton, J \& Stober, K. (eds) Monastic Wales, New Approaches, Cardiff: University of Wales Press, 73-88

Bender, B. (ed) 1993, Landscape, Politics and Perspectives. Oxford: Berg.

Beudry, M., Cook, L. J., \& Morozowski, S. 1991, Artefacts as active voices: material culture as social discourse. In R. McGuire \& R. Paynter (eds), The Archaeology of Inequality, 150-190. Oxford: Basil Blackwell.

Bezant, J. 2014, 'Revising the Monastic Grange: Problems at the Edge of the Cistercian World', The Journ. of Med. Monast. Stud. 3, 51-70.

Black, R. 2005, The Gaelic Otherworld. Edinburgh: Birlinn.

Bourdieu, P. 1977, Outline of a Theory of Practice. Cambridge: Unversity Press.

Boyle, S. 2003, 'Ben Lawers: an Improvement-period landscape on Lochtayside, Perthshire'. In S. Govan (Ed.), 2003.

Branigan, K., \& Foster, P. 2000, From Barra to Berneray: archaeological survey and excavation in the southern isles of the Outer Hebrides. Sheffield: Sheffield Academic Press.

Branigan, K., \& Foster, P. 2002, Barra and the Bishop's Isles: living on the margin. Stroud: Tempus. Butler, L.A.S., 1963, 'The Excavation of a Long-Hut Near Bwlch-yr-Hendre,' Ceredigion, IV, 450457. 
Caird, J., \& Proudfoot, B. 1987, 'Obituary: Dr Horace Fairhurst'. Scott. Geograph. Journ. 103(2), 109.

Caldwell, D., \& Ewart, G. 1998, 'Excavations at Eyemouth, Berwickshite, in a mid 16th century trace italienne Fort'. Post-Med. Archaeol. 31, 61-119.

Campbell, S. 2009, 'Post-Medieval Settlement in the Isle of Lewis: a study in adaptability or change?'. Proc. Soc. Antiq. Scot. 139, 315-322.

Cowley, D., \& Harrison, J. 2001, "Well Shelter'd and Watered": Menstrie Glen, a farming landscape near Stirling. Edinburgh: RCAHMS.

Crawford, I. 1967, 'The divide between medieval and post-medieval in Scotland'. Post-Med. Archaeol. 1, 84-89.

Cressey, M., Johnston, M., Haggarty, G., Turnbull, J., \& Hugh, W. 2012, 'Eighteenth-century glass and pottery manufacture at Morison's Haven, prestongrande, East Lothian'. Post-Med. Archaeol. 46(1), 36-55.

Coulson, C. 2003, Castles in Medieval Society: Fortresses in England, France and Ireland in the Central Middle Ages. London: Oxford University Press.

Curwen, E. C. 1938, 'The Hebrides: A Cultural Backwater'. Antiquity, 12, 261-289.

Dalglish, C. (2000), Rural Settlement in the Age of Reason: An Archaeology of the southern Scottish Highlands from the sixteeth to nineteenth centuries A.D. $(\mathrm{PhD})$, Unpublished $\mathrm{PhD}$ thesis, University of Glasgow, Glasgow.

Dalglish, C. 2001, 'Rural Settlement in the Age of Reason: Archaeologies of Capitalism and the Recent History of Highland Scotland'. Archaeol. Dialog. 8 (1).

Dalglish, C. 2002, 'Highland Rural Settlement Studies: a Critical History'. Pro. Soc. Antiq. Scot. 132, 475-497.

Dalglish, C. 2003, Rural Society in the Age of Reason. New York: Kluwer Academic/Plenum Publishers

Dalglish, C. 2005, 'An age of transition? Castles and the Scottish Highland estate in the 16th and 17th centuries'. Post-Med. Archaeol. 39 (2), 243-266. 
Dalglish, C. 2010, 'For the Community: Scottish Historical Archaeology and the Politics of Land Reform'. Intern. Journ. of Hist. Archaeol. 14, 374-397.

Dalglish, C. (ed) 2013, Archaeology, the Public, and the Recent Past. Woodbridge: The Boydell Press.

Deetz, J. 1977, In Small Things Forgotten: The Archaeology of Early American Life. Doubleday New York: Anchor Press.

Denholm, P. C. 1982, 'Mid-18th century tin-glazed earthenwares from the Delftfield Pottery Glasgow: excavation at the Broomielaw, 1975, with a note on ceramic exports from the Clyde, 1742-1773'. Post-Med. Archaeol. 16, 39-84.

Devine, T. 1994, Clanship to Crofters War: The Social Transformation of the Scottish Highlands. Manchester: University press.

Devine, T. 2006, Clearance and Improvement: Land, Power and People in Scotland 1700-1900. Edinburgh: John Donald.

Dodgshon, R. 1993, 'West Highland and Hebridean Settlement Prior to Croft and the Clearances: A study in stability or change?'. Proc. Soc. Antiq. Scot. 123, 419-438.

Dodgshon, R. 1998, From Cheifs to Landlords: Social and Economic Change in the Western Highlands and Islands c 1493-1820. University Press: Edinburgh.

Dodgshon, R. 2000, 'The Evolution of Highland Townships During the Mediveal and Ealy Modern Periods'. Landscape Hist. 20, 51-63.

Donnachie, I., \& Whatley, C. (eds) 1992, The Manufacture of Scottish History. Edinburgh: Birlinn. Driscoll, S., \& Dalglish, C. 2010, 'An International Scottish Historical Archaeology?'. Intern. Journ. of Hist. Archaeol. 14, 309-315.

Dunbar, J. G. 1992, 'The Royal Commission on the Ancient and Historical Monuments of Scotland: the first eighty years'. Trans. Anc. Mon. Soc. 36, 13-77.

Edwards, N. (ed.), 1997, Landscape and Settlement in Medieval Wales. Oxbow Monograph, 81. Fairhurst, H. 1960, 'Scottish Clachans'. Scott. Geograph. Mag. 7 6(7), 67-76.

Fenton, A. 1976, Scottish Country Life. Edinburgh: John Donald. Fenton, A. 1986, The Shape of the Past: Essays in Scottish Ethnology. Edinbugh: Donald. 
Fenton, A. 1987, Country life in Scotland: our rural past. Edinburgh: John Donald.

Ferguson, L. 2008, 100 years of recording Scotland's Treasured Places. Edinburgh: RCAHMS.

Fleming, A. 1998, Swaledale: valley of the wild river, Edinburgh, Edinburgh University Press.

Fleming, A, 2007, 'Don't Bin Your Boots!' Landscapes, 8:1, 85-99.

Fleming, A. and Barker, L., 2008 'Monks and local communities: the late-medieval landscape of

Troed y Rhiw, Caron Uwch Clawdd, Ceredigion', Med. Arch. 52, 261-90

Fox, A, 1939, 'Early Welsh Homesteads on Gelligaer Common, Glamorgan. Excavations in 1938'.

Arch. Camb. 94, 163-199.

Gazin-Schwartz, A. 2001, 'Archaeology and Folklore of Material Culture'. Intern. Journ. of Hist.

Archaeol. 5(4), 263-280.

Gazin-Schwartz, A., \& Holtorf, C. (eds) 1999, Archaeology and Folklore. London: Routledge.

Geddes, G. 2013, 'Archaeology at the margins - RCAHMS emergency survey in the 1950s'. Proc.

Soc. Antiq. Scot. 143, 363-391.

Given, M. 2004, Archaeology of the Colonized: London: Routledge.

Glassie, H. 1982, Passing the Time in Ballymenone. Indiana: University Press.

Glendinning, M., \& Martins, W. 2008, Buildings of the Land: Scotland's Farms 1750-2000.

Govan, S. 2003, Medieval or Later Rural Settlement in Scotland: 10 years On. Paper presented at the Spring Conference of the Medieval Settlement Research Group in Association with Historic Scotland, University of Edinburgh.

Grant, I. F. 1924, Everyday Life on an Old Highland Farm. London: Longmans \& Green.

Grant, I. F. 1960, Highland Folk Ways. London: Routledge and Kegan Paul.

Grant, K. 2014, '“.... and in Every Hamlet a Poet.”: Gaelic Oral Tradition and Postmedieval Archaeology in Scotland.'. Hist. Arch., 48 (1).

Grant, K. 2016 (forthcoming), 'Mo Rùn am Fearann' - 'My Love is the Land': Gaelic Landscapes of the 18th and 19th Centuries. (PhD), University of Glasgow, Glasgow.

GUARD 1995, Medieval or Rural Settlement (MOLRS) Study: Recommendations towards a policy statement. Glasgow: GUARD. 
Hanke, T. 2012, 'Newark Castle, Port Glasgow: a proto-modern roof of the late 16th century'. PostMed. Archaeol. 46 (1), 1-35.

Historic Scotland 1998, Medieval or Later Rural Settlement - Historic Scotland's Approach. . Edinburgh: Historic Scotland.

Hodder, I. 1986, Reading the past: Cambridge: University Press.

Horning, A., \& Palmer, M. (eds) 2009, Crossing Paths or Sharing Tracks? Boydell Press: Woodbridge.

Hoskins, W. G. 1955, The making of the English landscape. London: Hodder and Stoughton. Hume, J. 1976, The Industrial Archaeology of Scotland of Scotland. Vol 1. The Lowlands and Borders, (Vol. 1). London: Batsford.

Hume, J. 1977, The Industrial Archaeology of Scotland of Scotland. Vol 2. The Highlands and Islands, (Vol. 2). London: Batsford.

Hunter, J. 1976, The Making of the Crofting Community. Edinburgh: John Donald.

Ingold, T. 1993, 'The Temporality of Landscape'. World Arch. 25(2), 152-174.

James, H. \& Moore, P. 2009, 'Carmarthenshire and Beyond: Studies in History and Archaeology in Memory of Terry James', Llandybie: Carmarthenshire Antiquarian Society.

Johnson, M. 1996, An Archaeology of Capitalism. Massachusetts: Blackwell Publishers.

Johnson, M. 2002. Behind the Castle Gate: Medieval to Renaissance. London: Routledge Johnson, M. 2007a, 'Don’t bin your brain!', Landscapes, 8(2), 126-128.

Johnson, M. 2007b, Ideas of Landscape, Oxford: Blackwell.

Johnson, M. 2010 (2 $2^{\text {nd }}$ ed.), Archaeological Theory: An Introduction, Oxford,Wiley.

Lefebvre, H. 1991 The Production of Space, Oxford: Wiley-Blackwell.

Lelong, O. 2000, 'The prospect of the sea: responses to forced coastal resettlement in nineteenth century Sutherland'. In J. B. Atkinson, I \& McGregor,G (eds) 2000, 217-224.

Lelong, O. \& Wood, J. 2000, 'A township through time: excavation and survey at the desered settlement of Easter Raitts, Badenoch 1995-99'. In J. Atkinson, I. Banks \& G. MacGregor (eds) 2000, Leone, M. 1995, 'A Historical Archaeology of Capitalism'. American Anth.97, 251-268. 
Lewis, T. 1927, 'Archaeological Investigations in the Vicinity of Llanddewibrefi and Llanfair

Clydogau', Trans. of the Cards.Antiq. Soc. 5, 83-99.

MacGregor, G., Lelong, O., \& Johnston-Smith, D. 1999, Tigh Vectican, Arrochar. Glasgow: Guard.

MacKay, D. 1988, 'The Western Highlands and Islands: A Cultural Backwater'. Scottish Arch. Rev. 5, $110-114$.

Mackie, C. 2006, 'The Development of Traditional Housing in the Isle of Lewis: social and cultural influences on vernacular architecture'. Béaloideas, 74, 65-102.

Mackie, C. 2008, 'A Social History of Houses: the Hebridean Example'. Proceedings of the 22nd Annual Harvard Celtic Colloquium, 22, 141-155.

Meek, D. 1995, Tuath is Tighearna/ Tenants and Landlords, (Vol. 18). Edinburgh: Scottish Academic Press.

Mitchell, A. 1880, The Past in the Present: What is civilization? Edinburgh: D.Douglas.

Monbiot, G. 2015, Feral, Searching for Enchantment on the Frontiers of Rewilding, London: Penguin.

Morrison, A. 1977, 'The Question of Celtic Survival or continuity in some elements of rural settlement in the Scottish Highlands'. In L. Laing (ed) 1977.

Morrison, A. 2000, 'Scottish Rural Settlement Studies: Retrospect and Prospect'. In J. Atkinson, I. Banks \& G. McGregor (eds) 2000.

Muir, T. S. T., F.W.L. 1860, 'Notice of a Beehive House in the island of St Kilda'. Proc. Soc. Antiq. Scot. 3, 225-232.

Newman, R. 2005, 'Farmers and fields: developing a research agenda for post-medieval agrarian society and landscape', Post-Med. Archaeol. 39:2, 205-214.

Newton, M. (ed) 2006, Dùthchas Nan Gàidheal: Selected Essays of John MacInnes. Edinburgh: Birlinn.

Orser, C. 1996, A historical archaeology of the modern world. New York: Springer.

Owen, A. 1841 Ancient Laws and Institutions of Wales. Volume II. London: Record Commissioners, Public Record Office. 
Parker Pearson, M. (ed) 2012, From Machair to Mountains: Archaeological Survey and Excavation in South Uist (Vol. 4). Oxford: Oxbow Books.

Parker Pearson, M., \& Zvelebil, M. 2014, Excavations at Cill Donnain. Oxford: Oxbow Books.

Peate, I.C. 1940, 'The Welsh House - A Study in Folk Culture', Y Cymmrodor, 47.

Photos-Jones, E., Dalglish, C., Coulter, S., Hall, A. J., Ruiz-Nieto, R., \& Wilson, L. 2008, 'Between archives and the site: the 19th-century iron and steel industry in the Monklands, Central Scotland'. Post-Med. Archaeol. 42 (2), 157-180.

Portocarrero, G. 2011, 'Coastal defence systems in Arrábida, Portugal, during the early modern era: power and landscape', Post-Med. Archaeol. 45:2, 291-306.

RCAHMS 1971-1992, Royal Commission on the Ancient and Historical Monuments of Scotland. Argyll, an Inventory of Ancient Monuments. Vols 1-7. Edinburgh: RCAHMS.

RCAHMS 1993, Waternish, Skye and Lochalsh District: An archaeological survey (Afforestable Land Survey). Edinburgh: RCAHMS.

RCAHMS 2011a, A Practical Guide to Recording Archaeological Sites. Edinburgh: Royal Commission on the Ancient and Historic Monuments of Scotland.

RCAHMS 2011b, Scotland's Rural Past: Community Archaeology in Action. Edinburgh: The Royal Commission on the Ancient and Historic Monuments of Scotland (RCAHMS).

RCAHMS 1990, North-east Perth: An Archaeological Landscape. Edinburgh: RCAHMS.

RCAHMS 1994, South-east Perth: An Archaeological Landscape. Edinburgh: RCAHMS.

RCAHMS 2007, In the Shadow of Bennachie: An Archaeology of Donside, Aberdeenshire.

Edinbrugh: Royal Commission on the Historic Monuments of Scotland.

RCAHMS, \& Historic Scotland 2002, 'But the walls remained: a survey of unroofed rural settlement depicted on the first edition of the Ordnance Survey 9-inch map of Scotland". Edinburgh: RCAHMS. RFAW, 2011, 'A Research Framework for the Archaeology of Wales Version 02, Final Paper February 2011 Post Medieval (1539-1750)' Unpublished report, Wales: Research Framework for the Archaeology of Wales.

Rainbird, P. (ed.) 2008, Monuments in the Landscape, Stroud: Tempus. 
Rippon, S. 2007, 'Historic Landscape Characterisation: Its Role in Contemporary British Archaeology and Landscape History', Landscapes 2, 1-14.

Roberts, K. (ed.) 2006, Lost Farmsteads. Deserted Rural Settlements in Wales. York: Council for British Archaeology.

Sambrook, P. 2006, Deserted rural setltements in south-west Wales, in Roberts, 2006, 83-110.

Sayce, R.Y. 1956, 'The Old Summer Pastures. A Comparative Study'. Mont.Coll. 54, 117-145.

Sayce, R.Y. 1957, 'The Old Summer Pastures. Life at the Hafod', Mont.Coll. 55, 37-86.

ScARF 2012a, Modern Panel Executive Summary. Retrieved 03/05/2015, 2015, from

http://www.scottishheritagehub.com/content/executive-summary-4

ScARF. 2012b, Modern Panel, People and Landscape, Introduction. Retrieved 03/05/2015, 2015, from http://www.scottishheritagehub.com/content/8-people-and-landscape

Schweickart, E. 2014, 'Ideologies of consumption: colonialism and the commodification of goods in 18th-century Virginian and Lowland Scottish Rural households'. Post-Med. Archaeol. 48(2), 398-411. Scottish Archaeological Research Framework 2012, Modern Scotland: ScARF Panel Report.

Edinburgh: Society of Antiquaries of Scotland.

Shanks, M., \& Tilley, C. 1987, Re-constructing Archaeology. Cambridge: University Press.

Symonds, J. 1999a, 'Songs remembered in Exile?'. In A. Gazin-Schwartz \& C. Holtorf (eds) 1999a, Symonds, J. 1999b, 'Toiling in the Vale of Tears: Everyday life and resistance in South Uist, Outer Hebrides, 1760-1860'. Int. Journ. of Hist. Archaeol. 3 (2), 101-122.

Symonds, J. 2000, 'The dark island revisited: an approach to the historical archaeology of Milton, South Uist'. In J. B. Atkinson, Ian \& McGregor,Gavin (eds) 2000, 197-210.

Tarlow, S. 2007, The Archaeology of Improvement: Britain 1750-1850. Cambridge: Cambridge University Press.

Tarlow, S. 2008, Who are you calling marginal? A nineteenth century squatter settlement in upland Wales, in Rainbird, 2008, 177-189.

Thomas, F. W. L. 1857, 'Notice of Beehive Houses in Harris and Lewis; with Traditions of the Eachuisge, or Water-horse, connected therewith'. Proc. Soc. Antiq. Scot. 3, 127-144. 
Thomas, F. W. L. 1870, 'Notices of Three Chruches in North Uist, Benbecula and Grimsay, said to have been built in the Fourteenth Century'. Proc. Soc. Antiq. Scot. 9, 368.

Thomas, J. 1996, Time, Culture and identity: An interpretive archaeology: London: Routledge.

Thomson, D. 1994, The Companion to Gaelic Scotland. Glasgow: Gairm.

Tilley, C. 1994, Phenomenology of Landscape: Oxford: Berg.

Triggs, J.R. 2011, "'A brave cedar house": landscape archaeology at the Overplus House and Grove', Post-Med. Archaeol. 45:1, 144-182.

Turner, R. 2003, 'The Ben Lawers Historic Landscape Project'. In S. Govan (ed) 2003.

Ward, A. 1997, 'Transhumance and Settlement on the Welsh Uplands: A View from the Black Mountain'. In Edwards 1997, 97-112.

Webster, J. 1999, 'Resisting Traditions: Ceramics, Identity and consumer choice in the Outer Hebrides from 1800 to the Present'. Int. Journ. of Hist. Archaeol. 3 (1), 53-73.

Withers, C. 1992, 'The Historical Creation of the Scottish Highlands.'. In I. Donnachie \& C. Whatley (eds) 1992, 143-157.

Wmffre, I. 2009, 'Toponomy and Land-use in the Uplands of the Doethie Valley (Cardiganshire)', in James and Moore 2009, 270-283.

Yentsch, A. 1994, A Chesapeake Family and their Slaves. Cambridge: Cambridge University Press.

\footnotetext{
${ }^{1}$ Hoskins $1955,14$.

${ }^{2}$ Lefebvre 1991, 26.

${ }^{3}$ Johnson 2010, 235

${ }^{4}$ Dalglish 2002; SCARF 2012.

${ }^{5}$ Triggs 2011

${ }^{6}$ Fleming 2008

${ }^{7}$ Johnson 2007a; 2007b

${ }^{8}$ Portocarrero 2011

${ }^{9} 2002,2003,1984$

${ }^{10}$ Portocarrero 2011, 306

${ }^{11}$ Portocarrero 2011, 306

${ }^{12}$ Newman 2005

${ }^{13}$ For instance, the Research Framework for the Archaeology of Wales http://www.archaeoleg.org.uk/intro.html

${ }^{14}$ Newman 2005, 210.

${ }^{15}$ Driscoll \& Dalglish 2010; Morrison 2000.

${ }^{16}$ Driscoll \& Dalglish 2010, 311.

${ }^{17}$ Dalglish 2002; Govan 2003; Morrison 2000.
} 
${ }^{18}$ Muir 1860; F. W. L. Thomas 1857, 1870.

${ }^{19}$ Curwen 1938; Mitchell 1880.

${ }^{20}$ Dalglish 2002 482-484.

${ }^{21}$ e.g.I. F. Grant 1924.

${ }^{22}$ I. F. Grant 1924; 1960.

${ }^{23}$ Fenton 1976; 1986; 1987.

${ }^{24}$ Black 2005; Newton 2006; Thomson1994.

${ }^{25}$ Hume, 1976; 1977.

${ }^{26}$ Driscoll \& Dalglish 2010, 312.

${ }^{27}$ Driscoll \& Dalglish 2010, 312.

${ }^{28}$ Caird \& Proudfoot 1987.

${ }^{29}$ Fairhurst 1960.

${ }^{30}$ Fairhurst 1960, 73.

${ }^{31}$ Dalglish 2002, 485.

${ }^{32}$ Crawford 1967.

${ }^{33}$ Crawford 1967, 84.

${ }^{34}$ e.g. Morrison 2000

${ }^{35}$ Dalglish 2002, 485.

${ }^{36}$ Dunbar 1992; Ferguson 2008; Geddes 2013, 364.

${ }^{37}$ Cowley \& Harrison 2001; Glendinning \& Martins 2008; RCAHMS 1993; 1990; 1994; RCAHMS \& Historic Scotland 2002.

${ }^{38}$ Campbell 2009; Dodgshon 1993; 1998; 2000;

${ }^{39}$ GUARD 1995; Historic Scotland, 1998.

${ }^{40}$ Govan 2003.

${ }^{41}$ J. Atkinson, Banks, \& MacGregor 2000.

${ }^{42}$ J. Atkinson 2000; Boyle, 2003; Turner, 2003.

${ }^{43}$ J. Atkinson et al. 2005.

${ }^{44}$ RCAHMS 2011a; 2011b.

${ }^{45}$ RCAHMS 1971-1992; 1993; 1990; 1994; 2007

${ }^{46}$ much of the work described in Govan 2003; Morrison 1977.

${ }^{47}$ Lelong \& Wood 2000; MacGregor, Lelong, \& Johnston-Smith 1999.

${ }^{48}$ Dalglish 2002.

${ }^{49}$ Dalglish 2002, 490-493.

${ }^{50}$ J. Atkinson et al. 2000.

${ }^{51}$ Hodder, 1986; Shanks \& Tilley 1987; J. Thomas 1996; Tilley 1994.

${ }^{52}$ Lelong 2000

${ }^{53}$ Ingold 1993.

${ }^{54}$ Tilley 1994.

${ }^{55}$ Campbell 2009, 318.

${ }^{56}$ Dalglish 2000; 2001; 2003.

${ }^{57}$ e.g. Bourdieu 1977.

${ }^{58}$ Johnson 1996; Leone 1995; Orser 1996.

${ }^{59}$ Dalglish 2005.

${ }^{60}$ Dalglish 2001; 2003.

${ }^{61}$ Given 2004

${ }^{62}$ Adamson 2008.

${ }^{63}$ Adamson 2014

${ }^{64}$ Driscoll \& Dalglish 2010.

${ }^{65}$ Symonds 2000.

${ }^{66}$ Symonds 1999a; 1999b; 2000.

${ }^{67} 1977,1993,1994,1993$.

${ }^{68}$ Gazin-Schwartz 2001; Gazin-Schwartz \& Holtorf 1999; Glassie 1982.

${ }^{69}$ Beudry, Cook, \& Morozowski 1991; Deetz 1977; Yentsch 1994.

${ }^{70}$ Gazin-Schwartz 2001; Webster, 1999.

${ }^{71}$ Mackie 20062008.

${ }^{72}$ Branigan \& Foster 2000' 2002; Parker Pearson 2012; Parker Pearson \& Zvelebil 2014.

${ }^{73}$ K. Grant 2014.

${ }^{74}$ K. Grant 2016 (forthcoming).

${ }^{75}$ J. Atkinson et al., 2000 
${ }^{76}$ Basu 2000,

77 Donnachie \& Whatley 1992; Withers 1992,

${ }^{78}$ Devine 1994 2006; Hunter 1976,

${ }^{79}$ Driscoll \& Dalglish 2010, 310,311.

${ }^{80}$ Basu 2000.

${ }^{81}$ Driscoll \& Dalglish 2010, 313.

${ }^{82}$ Dalglish 2010.

${ }^{83}$ Dalglish 2013.

${ }^{84}$ Driscoll \& Dalglish 2010, 314.

${ }^{85}$ D. Atkinson, 2012; Ballin 2012; Caldwell \& Ewart 1998; Cressey et al. 2012; Denholm 1982; Hanke 2012; Photos-Jones et al. 2008.

${ }^{86}$ Dalglish 2005.

${ }^{87}$ Schweickart 2014.

882015

${ }^{89}$ Peate 1940

${ }^{90}$ Fox 1939

${ }^{91}$ Butler 1963

92 Sayce 1956, 1957

${ }^{93}$ Ward, 1997.

${ }^{94}$ Allen 1979

95 2007, 10.

96 2007, 27.

97 2007, 48.

${ }^{98}$ Bezant 2014, 61

${ }^{99}$ Tarlow, 2008, 184-5

${ }^{100}$ 2007, 49 after Johnson 1996

${ }^{101}$ Wmffre 2009

${ }^{102}$ Sambrook 2006

${ }^{103}$ Sambrook wrote the assessment for South-West Wales for Dyfed Archaeological Trust (Cambria Archaeology at the time), other trusts: Gwynedd Archaeological Trust, Glamorgan Gwent and Clwyd Powys Archaeological Trusts.

${ }^{104}$ Owen 1841 for instance.

${ }^{105}$ Sambrook 2006, 102

${ }^{106}$ Sambrook 2006, 102

107 Sambrook 2006, 106

108 Johnson 2007

${ }^{109}$ Fleming 2007, 86

${ }^{110}$ Austin 2006

${ }^{111}$ Austin 2006, 193

${ }^{112}$ Welsh for 'to keep'.

${ }^{113}$ Austin 2007

114 Rippon 2007

115 2007, 93.

${ }^{116}$ Austin 2007, 94.

${ }^{117}$ LANDMAP stands for Landscape Assessment and Decision Making Process. It is still used but the CCW are now merged with the Environment Agency Wales and the Forestry Commission Wales into a single body; Natural Resources Wales (NRW). Many are concerned about protection and curation of the historic environment under this 'natural' environment focussed body with inevtiable pressure on resources.

118 2007, 98.

119 Austin 2007, 95.

${ }^{120}$ Austin 2007, 94.

${ }^{121}$ Austin 2007, 104.

122 See, for example, Austin 2012 \& 2103, Bezant 2013 and 2104, Fleming and Barker 2008.

${ }^{123}$ Aston and Gerrard 2013

${ }^{124}$ Fleming 1998

125 Tarlow 2007, 3

${ }^{126}$ Tarlow 2007, 5

$1272007,5$.

${ }^{128}$ ScARF 2012a. 
${ }^{129} \mathrm{http}: / / w w w . a r c h a e o l e g . o r g . u k / i n d e x . h t m l$

${ }^{130}$ RFAW 2011

131 RFAW 2011

${ }^{132}$ RFAW 2011

${ }^{133}$ Monbiot 2015 for instance

${ }^{134}$ Austin 2006, 194

${ }^{135}$ See Sayce 1956 and 1957 for instance

${ }^{136}$ Austin 2006, 196-7

${ }^{137}$ MacKay 1988.

${ }^{138}$ Dalglish 2002, 489.

${ }^{139}$ Devine 1994; 2006; Dodgshon 1998; Hunter 1976; Meek 1995.

${ }^{140}$ Campbell 2009, 318.

141 2007, 5.

142 ScARF 2012b.

${ }^{143}$ ScARF 2012b.

144 e.g Dalglish 2013; Horning \& Palmer, 2009. 